\title{
Towards the Semantic Web Expert System
}

\author{
Olegs Verhodubs ${ }^{1}$, Janis Grundspenkis ${ }^{2},{ }^{1-2}$ Riga Technical University
}

\begin{abstract}
The paper presents a conception of the Semantic Web Expert System which is the logical continuation of the expert system development. The Semantic Web Expert System emerges as the result of evolution of expert system concept and it means expert system moving toward the Web and using new Semantic Web technologies. The proposed conception of the Semantic Web Expert System promises to have new useful features that distinguish it from other types of expert systems.
\end{abstract} Web

Keywords: Artificial Intelligence, Expert Systems, Semantic

\section{INTRODUCTION}

It is difficult to overestimate the importance of expert systems for science, technology, and human life. An expert system is a computer program which operates with knowledge in some domain for producing recommendations or problem solving [1]. In general expert systems belong to knowledgebased systems (KBS).

The first expert systems were developed in 1960s. However, the research in this area was conducted for two previous decades. The first expert systems were DENDRAL and MYCIN [15]. DENDRAL was used for determining the structure of organic molecules, and MYCIN - for assisting physicians in diagnosis of blood disorders. After the mentioned expert systems, the first expert system for commercial use, namely R1/XCON was created by Hewlett Packard for configuring hardware orders.

Since then, researchers and engineers accumulated a lot of knowledge and information that allowed improving of expert system designing technology and reducing time of expert system constructing. As a result, thousands of very useful industrial expert systems are known in the world. The following few examples can be mentioned [16]: ARAMIS, NEUREX in the area of medicine, DAA, NASL, and QO in the field of electronics, AIRPLAN in transportation management, ANALYST and BATTLE for forecast of military operations, RAD and RUNE in economics.

Despite abundance of expert systems, recently the factor appeared which stimulated further development of expert systems. This factor is the Internet. It has already allowed implementing of Internet-based expert systems. These expert systems are accessible on the Internet. This is the main distinction of traditional expert systems from Internet-based expert systems [7].

Nowadays the Internet develops towards Semantic Web [4]. The Semantic Web provides new quality of the Internet, which means new quality of Internet-based expert systems. There are some projects in the area of expert systems, where the Semantic Web technologies are used. The framework of the system for assisting users through counseling on personal health is described in [11]. The results of the research about the semantic layer architecture for an educational tool are presented in [12].

In the paper the conception of an expert system which is based on the Semantic Web technologies is described. The paper is organized as follows. Section II gives an overview of expert system types. Section III describes Internet-based expert systems. Section IV presents the Semantic Web. Section V discusses the conception of the Semantic Web Expert System. Finally, conclusions are presented.

\section{II.STATIC AND DYNAMIC EXPERT SYSTEMS}

The long period of development of expert systems generated different types of expert systems. Despite this fact, it is possible to select a typical structure of a static expert system [15]. Such a structure consists of the following elements:

- Working memory;

- Knowledge base;

- Inference engine;

- Knowledge acquisition component;

- Explanation component;

- Dialogue component.

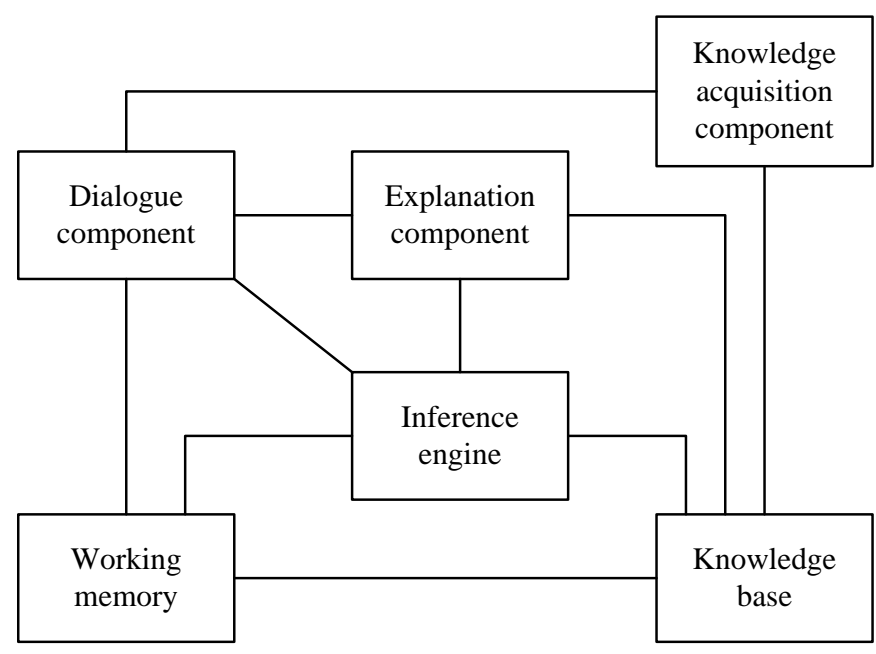

Fig. 1. The typical structure of a static expert system

It may be sensible to remind the purpose of each part of an expert system:

-Working memory is necessary for data storing which is used for current task solving;

- Knowledge base is necessary to store knowledge, which describes a domain; 
- Inference engine is a program that models expert's style of reasoning using knowledge from the knowledge base;

- Knowledge acquisition component automates the process of an expert system filling with data which is executed by an expert;

- Explanation component explains how the system executes the task solution and what knowledge that can facilitate testing and increase trust in the results is used;

- Dialogue component is focused on interaction with users to give the possibility of knowledge input and to show the results of task solution.

Besides static expert systems, there are dynamic expert systems [15]. The main difference between static and dynamic expert systems is that in static expert systems it is not possible to consider changes of the environment. Dynamic expert systems have to consider changes of the environment. Of course, the difference influences the structure of dynamic expert systems. Fig. 2 shows the typical structure of a dynamic expert system. The element denoted as "System" incorporates all elements from Fig. 1.

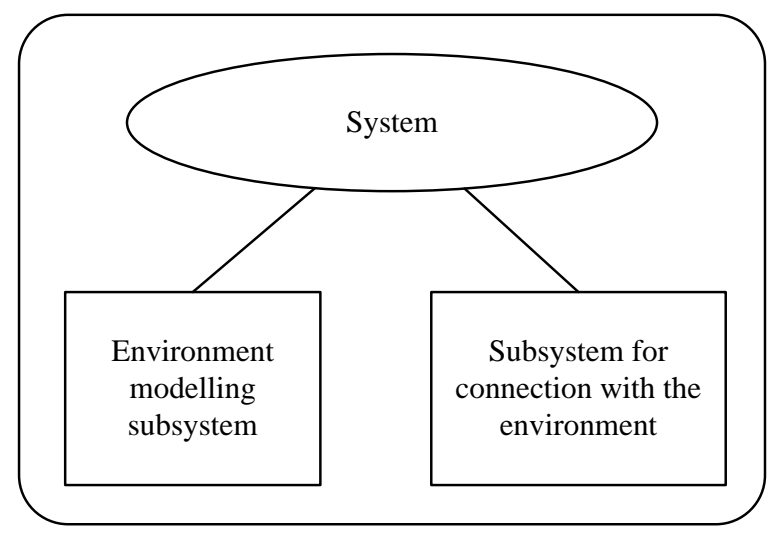

Fig. 2. The typical structure of a dynamic expert system [13]

In Fig. 2, the typical structure of a dynamic expert system is shown and from the picture it is clear that a dynamic expert system in comparison with a static system includes two additional subsystems:

- Environment modeling subsystem;

- Subsystem for connection with the environment.

These subsystems are aimed at interaction with the environment. The environment means the place where an expert system functions. So, the subsystems are able to notice different changes and to react to them.

The classification of static and dynamic expert systems is not the unique classification. Indeed, this classification cannot display all varieties of expert systems. The Internet allowed implementing of Internet-based expert systems and a new classification appeared: traditional and Internet-based expert systems.

\section{INTERNET-BASED EXPERT SYSTEMS}

So, the Internet has made big changes in human life in general and in the area of expert systems in particular. Earlier all expert systems were stationary and the limited number of people had an access to such systems. This limitation of the use of a resource certainly reduced economic feasibility of these systems.

Wide access of the Internet is the first very important but not the last advantage. Among other advantages it is necessary to mention [4]:

- Web-browsers provide a common multimedia interface;

- Several Internet-compatible tools for KBS development are available and expert systems belong to KBSs;

- Internet-based applications are inherently portable;

- Emerging protocols support co-operation among KBSs.

In spite of the fact that an expert system in the Internet is a relatively new phenomenon, there are a lot of these systems in different areas. Here are some examples of these fields [5]:

- Education and research (The Douglas Fir Cone and Seed Insects System, The Expert System for Thermodynamics, The Reptile Identification Helper, etc);

- Government (The OSHA Hazard Awareness Advisor, etc);

- Medicine (Willard, HEPAXPERT/WWW, The Protocol Assistant, Riva, etc).

Internet-based expert systems are based on traditional expert system technology, rule-based (i.e. using some rules) and case-based (i.e. using solutions of similar past problems) reasoning primarily, but they are transformed and adapted from usual designs to Internet use by incorporating clientserver architectures and Web browser based interfaces. Therefore, it is obvious that Internet-based expert systems have some design issues. One problem is rapid technological changes of servers, browsers, intelligent tools, programming languages, interface components, client-server software, and so on. It is difficult for developers to cope with emerging technology. Another problem, which is absent in stationary expert systems, is related to communication speed associated with the use of multimedia in expert systems. A rich variety of graphic, audio and visual materials require significant bandwidth for delivery. If users are restricted to the use of slower connections, or if many users access the system simultaneously, the communication requirements for multimedia components can create a bottleneck.

A typical structure of an Internet-based expert system is a traditional expert system structure that is supplemented by the Internet technologies [5].

It is clear from Fig. 3 that the typical structure of an Internet-based expert system consists of three main parts: a 
Client, a Server and the Internet. The client part consists of Web-browser that allows loading the interface part of the Internet-based expert system and using the resources of such an expert system. The server part basically consists of a set of HTTP-pages and a knowledge base. HTTP-pages are necessary for realization of interface and for support of expert system functionality. The knowledge base is the storage of rules. The Internet is the third part of the Internet-based expert system. It provides the communication channel for interaction between the client and server parts of the Internet-based expert system or for interaction between users and knowledge.

Comparing traditional and Internet-based expert systems displayed in Fig. 1 and Fig. 3 accordingly it is important to underline that knowledge bases in both systems correspond to each other. The element "HTTP-pages" in Fig. 3 corresponds to "Dialogue component", "Explanation component", "Working memory", "Knowledge acquisition component" and "Inference engine" in Fig. 1.

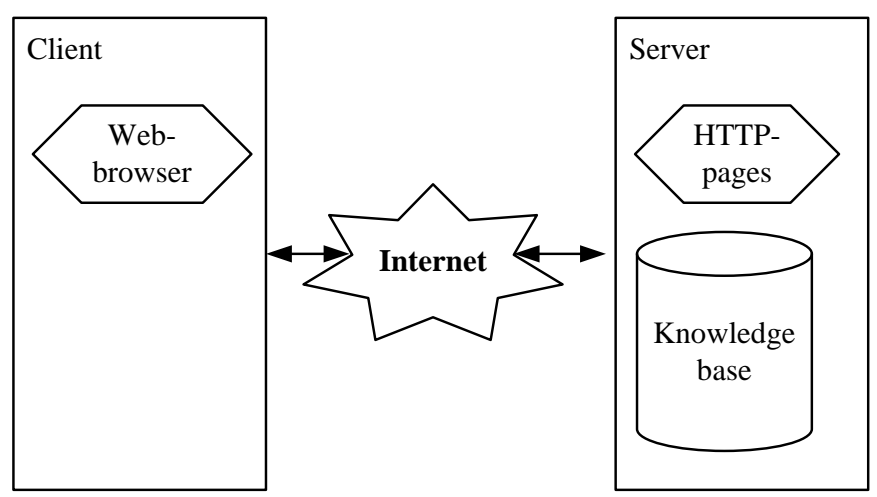

Fig. 3. The typical structure of Internet-based expert system [7]

As it has been mentioned above, one of the Internet-based expert system advantages is existence of several Internetcompatible tools for KBS development. In general, these tools employ traditional expert system techniques and offer in addition the capacity for Internet-based development. Here is the list of tools available for Internet-based expert system construction [5]:

- Acquire is an expert system shell that also includes a knowledge acquisition tool.

- ExSys is an expert system shell incorporating rulebased and fuzzy reasoning.

- The Java Expert System Shell (Jess) is an expert system shell in Java that processes a CLIPS-like rule-based language.

- KB Agent by Explore Reasoning Systems is an expert system shell based on the SOAR system of Allen Newell.

- XpertRule KBS is a rule-based expert system shell that interfaces over the Web with a thin client using Microsoft's Active Server Page technology.

The fact that expert systems move from local computers to the Web is a great step forward in the area of expert system development. It seems to be even more important step for the development of the Internet. Indeed, now the Internet is a huge heap of ill-matched information which is represented by means of different types of information blocks [4]. The Web has texts, pictures, movies, audio files. The last step of evolution of the Web was the implementation of data bases. However, it can help to classify information in the Internet and it is possible only to facilitate searching of information. But it does not add rationality to the Web. Constructing expert systems on the Internet, it is possible to add this rationality to it. This development step of the Internet adds intelligence to the network and transforms it from the directory to a consultant which can advise and give consultations in different areas of human activity for non-experts [6].

The only disadvantage of present expert systems in the Internet is the fact that they use the Web only as communication means. It is extremely depressing because the Internet has a lot of information that can be transformed into knowledge but knowledge is much demanded in each area of human activity. Here the problem is in data representation on the Internet. The data representation does not allow using data for machine reasoning. Of course, there are a lot of scientific methods for knowledge extraction from Web pages but all of them are not so good to use them where it is necessary [3]. Therefore it is important to find a better solution for this issue. One of the best solutions is to develop a new kind of data representation which will be more perfect and will transform the existing Web from the set of different information blocks to something more integrated with the possibility of reasoning. It is necessary to point out that there already is such technology that solves many problems and allows looking ahead with hope. Certainly, it is the Semantic Web [4].

\section{SEMANTIC WEB}

Technologies of the Semantic Web are the most perspective from the point of view of the Internet development. They promise to eliminate a lot of drawbacks inherent in the usual Internet where there is plenty of information which is very difficult to process.

So, the Semantic Web is a superstructure over the usual Internet that is intended for information which is placed in the Web to make it readable for computers [4]. It allows usage of more effective algorithms for data processing not requiring a human work for this purpose.

Machine processing in the Semantic Web is possible because of its two main features:

- Usage of Unified Resource Identifiers (URI). Traditionally these identifiers are used for reference definition on the addressed object (for example, Web page, file, or e-mail). On the Semantic Web URI are used for object reference too. Not only Web-pages have their own URI in the Semantic Web. Here URI belongs to real life objects (humans, towns, and so on). URI are globally unique. Therefore they allow naming the same objects in different places of the Semantic Web. 
- Usage of semantic networks and ontologies. Modern methods of data processing are based on the lexical analysis of text data that are intended for human perception. In the semantic network, the Resource Description Framework (RDF) standard is used. Statements coded with RDF are possible to interpret with ontologies that are created by means of RDF Schema and Web Ontology Language (OWL) standards [4].

The technical part of the Semantic Web comprises such standards as eXtensible Markup Language (XML), XML Schema, RDF, RDF Schema, OWL [4]:

- XML provides syntax of document structure definition for machine processing; XML has no semantics;

- XML Schema defines restrictions on XML document structure;

- RDF is a simple way to represent data in the format of subject-relation-object where each element of this triple is used only as a resource identifier;

- RDF Schema describes a set of attributes or relations for new types of RDF data definition;

- OWL expands opportunities for description of new types and allows defining new types of RDF Schema data in terms of existing types [11].

OWL is a knowledge representation language for constructing ontologies. Ontology is a formal, explicit specification of a shared conceptualization [2].

Metadata formats in the Semantic Web give the opportunity of logical inference on these metadata. A piece of software that is able to infer logical consequences from a set of asserted facts or axioms is called a reasoning engine or a reasoner. The notion of a semantic reasoner generalizes that of an inference engine by providing a richer set of mechanisms to work with. The inference rules are described by means of an ontology language, and often by means of a description language. Reasoners usually are based on first-order predicate logic. Existing semantic software reasoners are commercial or free. Examples of commercial software reasoners are:

- Bossam;

- OntoBroker;

- SHER;

- RacerPro;

- OWLIM.

Examples of free reasoners:

- Jena;

- KAON2;

- Prova;

- SweetRules;

- FACT;

- $\mathrm{FACT}++$

- Pellet.
According to the Semantic Web idea, its structure allows enabling some intelligent agents (i.e. some autonomous entities, which function in the environment to reach own purposes) to access the Web more intelligently. These agents will be able to perform tasks automatically and locate the needed information.

There are a lot of types of such agents [14] but all of them can be divided into two groups [10]:

- Reactive agents are agents that don't have representation of the environment;

- Mobile agents are agents that are able to move in the Web.

There are some programming libraries to construct such agents. One of the most perspective programming libraries for this purpose is Java Agent Development Framework (JADE) [2]. It is created to be used with Java programming language.

OWL and agent technology are very important for expert system construction because OWL can be used for knowledge base programming and agent technology can be used for semantic knowledge processing.

\section{V.SEMANTIC WEB EXPERT SYSTEM}

Traditional expert systems, Internet-based expert systems, limitations of Internet-based expert systems and new technologies of the Semantic Web were discussed in the previous sections. All this information helps to understand that disadvantages of existing traditional and Internet-based expert systems and also the new possibilities of the Semantic Web technologies are preconditions for constructing a new type of expert systems with a set of useful features and without the mentioned disadvantages. This expert system can be called a Semantic Web Expert System because it uses the Semantic Web technologies.

\section{A. Structure of the System}

It is thought that the semantic web expert system is the expert system which uses the Semantic Web technologies for more integrity with the future Web when the Semantic Web technologies force out the traditional Internet. Therefore, it is possible to assert that such a semantic web expert system will be a part of the Internet. The fact of transformation of traditional expert systems from systems which use the Web to the systems that are the part of the Internet will give possibility to save computing resources, because it will not be necessary to transform data from the Web representation to expert system representation.

Besides, the feature of semantic web, expert system data integrity with the environment (the Internet) transforms the Web from the communication channel which serves as the means for data exchange to the general environment where data are collected, searched for and transformed for user's advantages. Identical technologies for the Web and for the 
semantic web expert system raise the importance of the semantic web expert system structure of knowledge management.

The structure of the semantic web expert system is very similar to the structure of the traditional expert system in the sense that the former also contains the knowledge base, the inference engine, the knowledge acquisition component, the explanation component, and the dialogue component. However, the new expert system is very similar to the Internet-based expert system, too. It also uses the Internet and Web-browser to display the interface of the expert system. The proposed conception of the semantic web expert system also concerns Semantic Web because it is planned to use the Semantic Web technologies for the internal semantic web structure component construction. So, it may be foreseen that the semantic web expert system will integrate new technologies and achievements of expert system evolutionary development. This approach gives hope for success.

Speaking about the expert system structure in particular, it is necessary to note that the offered structure of the system is not definitive and can be changed because of practical requirements. At the moment, the conception of the semantic web expert system has the structure which is represented in Fig. 4. This structure consists of three main parts: a client, a server, and the Internet.

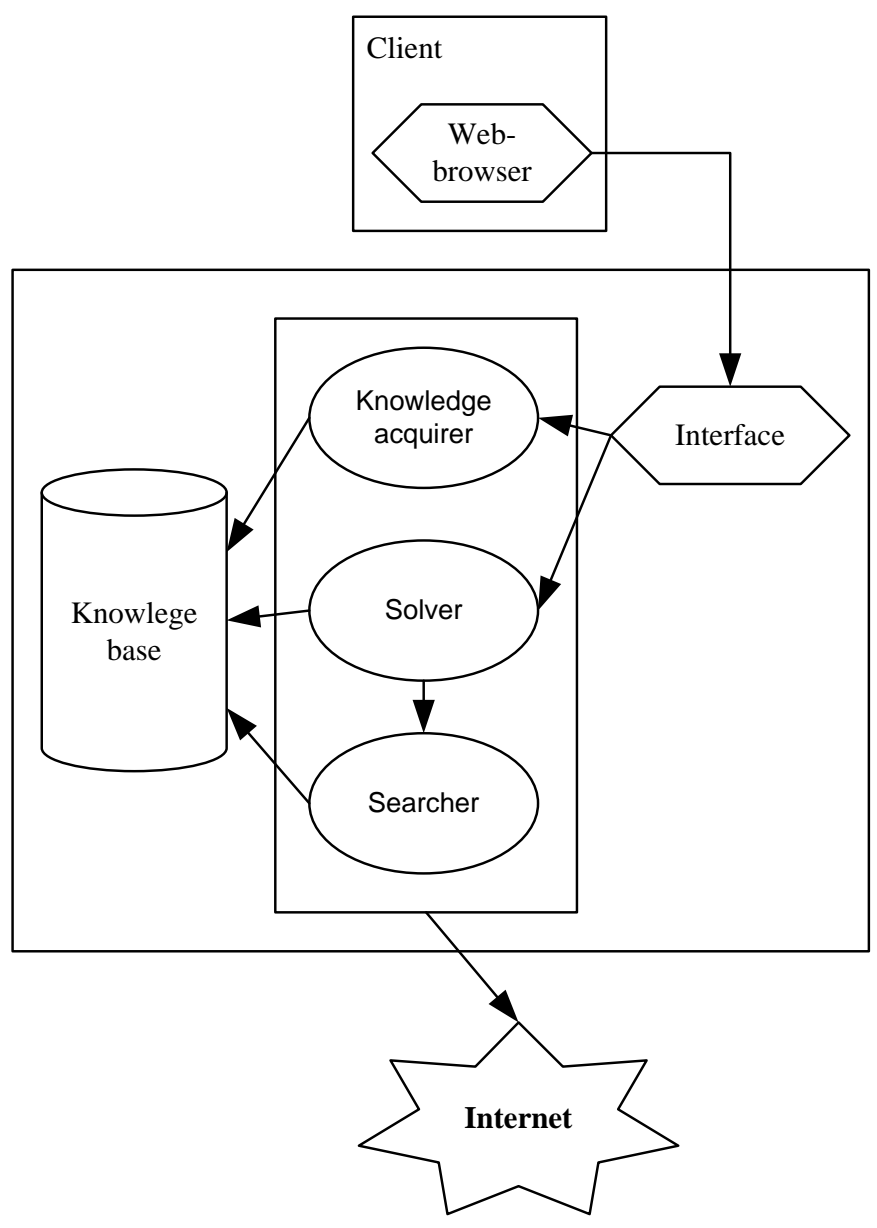

Fig. 4. The Semantic Web Expert System structure
The client part is similar to the client part of the Internetbased expert systems which structure is shown in Fig.3. This part is presented by Web-browser which gives possibility to get the access to the interface of the semantic web expert system.

The main part of the expert system is the server part. It contains:

- the knowledge base;

- the multi-agent system (i.e. the system, which consists of a lot of intelligent agents, which interact);

- the interface.

Here the multi-agent system has three agents: the knowledge acquirer, the solver, and the searcher. It is thought that the knowledge base is constructed using OWL for knowledge storage. The agent "Knowledge acquirer" is necessary for addition of knowledge to the knowledge base. The agent carries out the interaction between the user of the expert system and the knowledge base. The "Solver" agent is the inference engine and this is the element of the system that allows processing of user queries for making conclusions. The "Searcher" is the agent that looks for possibilities of expanding the knowledge base if the "Solver" cannot make conclusions using data and rules of knowledge base. The interface of the semantic web expert system also consists of Web-pages. It is similar to the Internet-based expert systems shown in Fig. 3.

The last part of the described system is the Internet. The Web is the environment of presented expert system and it is a great body of data and knowledge.

Comparing the typical structure of a static expert system in Fig. 1 and the semantic web expert system in Fig. 4, it is necessary to mention that Knowledge Bases in Fig. 1 and Fig. 4 correspond to each other, the Knowledge Acquisition component in Fig. 1 corresponds to the agent "Knowledge acquirer" in Fig. 4, the element "Inference engine" in Fig. 1 corresponds to the agent "Solver" in Fig. 4, the elements "Working memory", "Dialogue component", and "Explanation component" in Fig. 1 correspond to the "Interface" in Fig. 4. The element "Searcher" in Fig. 4 does not correspond to any of the components in Fig. 1 because the typical structure of a static expert system does not have the function of knowledge expanding from the Internet.

\section{B. System Operation Modes}

The semantic web expert system can work in two modes. The first mode is intended for knowledge input to the knowledge base. This mode is provided for the expert who inputs the knowledge into the system.

The second mode is designed for the user who uses the expert system to get the needed recommendations from the system. It is necessary to note that if the expert system cannot process user's query then the "Searcher" agent looks for the needed knowledge on the Internet. If it is found, the agent supplements the knowledge base and forms an answer to 
user's query. Certainly, it is not planned to integrate some algorithms for knowledge extraction from the traditional Web [1]. It is thought that the Internet will be transformed to the Semantic Web and the needed knowledge can be easily extracted from the Web.

\section{Implementation Issues}

There are a lot of problems related to the implementation of such a semantic web expert system. However, it seems that it may be sensible to be engaged in research in this field. Indeed, this system promises to be an essentially new expert system because it will be able to expand knowledge base with knowledge from the Web. There are some questions that will appear in the process of the expert system constructing:

- Where to look for new knowledge?

- How to determine that the resource similar to the domain of the expert system is found?

- How to expand the knowledge base with new knowledge?

- How to determine that the found resource deserves trust?

- What structure of knowledge base will be the best for knowledge addition?

There are certainly also other issues to be solved for implementation of this expert system which are not mentioned above and which can hardly be predicted at this initial stage of research.

\section{Advantages}

Despite the semantic web expert system realization issues, such an expert system has advantages in comparison with traditional and Internet-based expert systems. The semantic web expert system as well as Internet-based expert system has access to the Internet. This is an advantage in comparison with traditional expert systems. It allows:

- Having more than one user for this system;

- Using Web-browser as a common user interface;

- Using this expert system everywhere, where there is the Internet;

- Using a lot of programming libraries and tools for construction of expert system (JADE, Jena and so on).

But there is an advantage of the semantic web expert system in comparison with traditional and Internet-based expert systems, too. This is the possibility of expansion of knowledge base using knowledge on the Internet if the semantic web expert system cannot answer user's query. This feature of training from the Internet distinguishes the conception of the semantic web expert system from other expert systems.

\section{E. Further Steps of Expert System Implementation}

The main purpose of the research is to implement such an expert system. There are some further steps of this expert system's implementation:

- To develop an interface of the semantic web expert system;

- To work out the structure of knowledge base;

- To determine an inference engine for the semantic web expert system;

- To develop the system of tests for the semantic web expert system to adjust its functioning.

It is thought that these steps have to lead to a more real prototype of the semantic web expert system.

\section{CONCLUSIONS}

The article has described traditional expert systems, Internet-based expert systems, and as the result the conception of the semantic web expert system has been proposed. The leap from Internet-based to semantic web expert system is not significant. The set of new technologies so called Semantic Web technologies (XML, XML Schema, RDF, RDF Schema, OWL, JADE, Jena and others) is presented as an intermediate link between Internet-based and semantic web expert systems. It allows noting the development direction, the trend in this field of knowledge.

It is necessary to understand that the trend of moving software to the Web has been recognized for a long time. The Internet is gradually transforming to the general information environment. It would be very strange if expert systems didn't pick up this tendency and expert systems followed the general trend. The first step of this tendency, as it has been mentioned above, was construction of Internet-based expert systems. Moving expert systems to the Internet is a very important stage in the development of these systems. But it is only the beginning of this process because the first expert systems use the Web as the general point of access to themselves. It would be an error to consider the Internet only as communication means. The Web is something more than communication.

The Internet is a huge body of data which has to be used. New technologies of the Semantic Web open new possibilities in knowledge representation. Obviously, expert systems should add to the arsenal new possibilities of the Semantic Web, too. The offered semantic web expert system is one of the possible decisions. As it is shown above, the semantic web expert system is able not only to accumulate knowledge working together with the human-expert, but also to work in automatic mode when knowledge base cannot provide the user of the system with necessary answer to the user's query. In this case this expert system looks for corresponding data in the Web, expands the knowledge base and gives the answer to the user's query. It is very important to add that as a result the knowledge base each time becomes richer with knowledge.

It is interesting that such an expert system can be transformed to the system with one working mode, that is, the working mode is not necessary when a human-expert inputs 
knowledge in the knowledge base. The point is that knowledge will be found on the Internet automatically. However, for this purpose some conditions must be met:

- Semantic Web technologies have to prevail on the Internet;

- Effective methods of knowledge search on the Internet must be developed.

It is possible that these issues will be solved in the future. It is planned that future work will be dedicated to the comparative analysis of different technologies in the semantic web expert system construction. After that, algorithms of knowledge base expanding by using knowledge from ontologies will be studied.

\section{REFERENCES}

[1] P. Jackson, Introduction to Expert Systems, $3^{\text {rd }}$ edition. Boston: AddisonWesley Longman Publishing Co., 2001.

[2] F. Bellifemine, G. Caire, T. Trucco and G. Rimassa, "JADE programmer's guide", 2010. [Online]. Available: http://jade.tilab.com/doc/programmersguide.pdf. [Accessed: May 10, 2010].

[3] P. Buitelaar, P. Cimiano, B. Magnini, "Ontology learning from text: an overview", 2003. [Online]. Available: http://www.aifb.uni-karlsruhe.de. [Accessed: Nov. 10, 2009].

[4] R. M. Colomb, Ontology and the Semantic Web. Amsterdam, NLD: IOS Press, 2007.

[5] I. M. Dokas, "Developing web sites for web based expert systems: A Web Engineering Approach", 2005. [Online]. Available: http://loma.civil.duth.gr. [Accessed: Nov. 15, 2009].

[6] Y. Duan, J. S. Edwards and M. X. Xu, "Web-based expert systems: benefits and challenges", 2004. [Online]. Available: http://www.sciencedirect.com. [Accessed: Dec. 5, 2009].

[7] R. Grove, "Internet-based expert systems", 2000. [Online]. Available: http://www.fing.edu.uy. [Accessed: Dec. 5, 2009].

[8] S. Russell and P. Norvig, Artificial Intelligence. A Modern Approach. Prentice Hall, Upper Saddle River, New Jersey, 2003.

[9] N. Stojanovic, S. Handschuh, "A framework for knowledge management on the semantic web", 2002. [Online]. Available: http://www2002.org. [Accessed: Dec. 15, 2009].

[10] D. Lewis, "Intelligent agents and the semantic web", October 2008. [Online].

Available:

http://www.ibm.com//developerworks/web/library/wa-intelligentage/. [Accessed: Sep. 29, 2010].

[11] C. Snae, M. Brueckner, "Personal Health Assistance Service Expert System (PHASES)", 2007. [Online]. Available: www.waset.org/journals/waset/v32/v32-31.pdf. [Accessed: Feb. 20, 2011].
[12] S. Linckels, C. Meinel, "Semantic Layer Architecture for an Educational expert System in Computer History", 2004. [Online]. Available: www.linckels.lu/Publications/AISTA2004_029-04_linckels.pdf. [Accessed: Feb. 20, 2011].

[13] Э. В. Попов, И. Б. Фоминых, Е. В. Кисель и М. Д. Шапот, Статические и динамические экспертные системы: Учеб. Пособие. М.: Финансы и статистика, 1996.

[14] Т. А. Гаврилова, В. Ф. Хорошевский, Базы знаний интеллектуальных систем. Учебник. Санкт-Петербург: ПИТЕР, 2000.

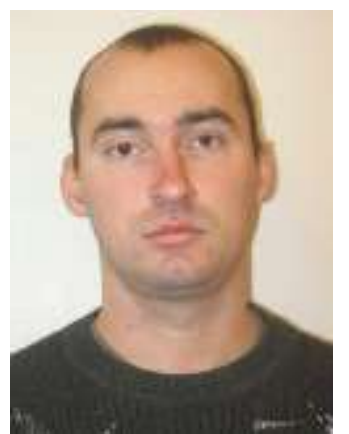

Olegs Verhodubs received a Bachelor Degree in 2001 and a Master Degree in computer science in 2004. Now he is engaged in expert knowledge representation and processing methods in intelligent tutoring systems.

Olegs Verhodubs worked as an engineer of computer technologies for 4 years. Now he works at Riga Technical University as the assistant on scientific work. He is interested in artificial intelligence, expert systems and the semantic web.

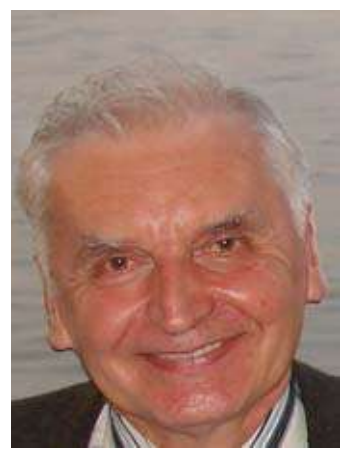

Janis Grundspenkis graduated from Riga Politecnical Institute (now Riga Technical University) in 1965. His major was electrical engineer of automation and telemechanics. $\mathrm{He}$ received his Dr.sc.ing. degree from Riga Polytechnic Institute in 1972 and his Dr.habil.sc.ing. degree in 1993 from Riga Technical University.

$\mathrm{He}$ is a professor of systems theory at Riga Technical University. He is also a Dean of the Faculty of Computer Science and Information Technology, the Director of the Institute of Applied Computer Systems, and the head of the Department of System

Theory and Design. His research interests are agent technologies, knowledge engineering and management, structural modeling for diagnostics of complex systems and development of intelligent tutoring systems.

$\mathrm{He}$ is a member of Institute of Electrical and Electronics Engineers (IEEE), Association of Computer Machinery (ACM) and International Association for Development of the Information Society (IADIS). He is a full member of Latvian Academy of Science.

Oḷegs Verhodubs, Jānis Grundspenkis. Semantiskā tīmek̦̣a ekspertu sistēma

Rakstā ir sniegts pārskats par ekspertu sistēmu attīstības tendencēm. Ir apskatītas tradicionālas un tīmekla ekspertu sistēmas un raksta beigās ir piedāvātas semantiskā tīmekḷa ekspertu sistēmas. Tradicionālās ir statiskās un dinamiskās ekspertu sistēmas, kuras strādā lokāli. Tīmekḷa ekspertu sistēmas ir tādas sistēmas, kuras strādā tīmeklī. Semantiskā tīmekḷa ekspertu sistēma ir ekspertu sistēma, kas strādā tīmeklī un lieto tādas tehnologijas, kā zināšanu atspoguḷšana ar ontoloǵiju aprakstīšanas valodu OWL un multiaǵentu sistēmu tehnoloǵiju izmantošana. Rakstā ir izklāstītas aprakstīto ekspertu sistēmu struktūras, priekšrocības un trūkumi. Atsevišķi ir aprakstìtas semantiskā tīmekḷa tehnologijijas, kuras ir piedāvāto semantiskā tīmekḷa ekspertu sistēmu pamatā. Ir parādīts, kāpēc semantiskā tīmekḷa tehnologijas var būt pielietotas ekspertu sistēmas konstruēšanai. Īpaša uzmanība ir pievērsta jaunajai ekspertu sistēmas koncepcijai un tās struktūrai, norādot sistēmas pamatkomponentes un to funkcijas. Rakstā detalizēti ir aprakstīti piedāvātās semantiskā tīmekḷa ekspertu sistēmas funkcionēšanas režīmi. Ir norādītas semantiskā tīmekḷa ekspertu sistēmas priekšrocības attiecībā pret tradicionālām un tīmekḷa ekspertu sistēmām, kā arī semantiskā tīmekḷa ekspertu sistēmu konstruēšanas problēmas. Nobeigumā ir identificēti semantiskā tīmekḷa ekspertu sistēmas turpmākās attīstības perspektīvas. Tiek domāts, ka piedāvātā semantiska tīmekḷa ekspertu sistēma būs spējīga patstāvīgi papildināt savu zināšanas bāzi, lietojot tīmekḷa resursus. Tas būs iespējams tikai tad, kad semantiska tīmekḷa tehnoloǵijas tiks plaši izmantotas tīmeklī. 
Олег Верходуб, Янис Грундспенькис. Экспертная система семантической сети

В данной статье дан обзор тенденций развития экспертных систем, описаны обычные, сетевые и экспертные системы семантической сети. Под обычными экспертными системами понимаются статические и динамические экспертные системы, работающие локально. Под сетевыми понимаются экспертные системы, работающие в глобальной сети Интернет. Экспертная система семантической сети - это экспертная система, которая работает в сети Интернет и использует такие технологии как представление знаний с помощью языка описания онтологий OWL и использование мультиагентных систем. В этой статье изложены преимущества, недостатки и структуры описанных экспертных систем. Отдельно в статье описаны технологии семантической сети, которые лежат в основе предложенной экспертной системы семантической сети. Показано, почему технологии семантической сети могут быть использованы при конструировании экспертных систем. Особое внимание уделено описанию концепции предложенной экспертной системы и ее структуры, включая основные компоненты и их функции. В статье детально описаны режимы функционирования предложенной экспертной системы семантической сети. Указаны преимущества экспертной системы семантической сети в сравнении с традиционными и сетевыми экспертными системами, а также указаны проблемы конструирования экспертных систем семантической сети. В заключении представлены идальнейшие перспективы развития экспертной системы семантической сети. Предполагается, что предложенная экспертная система будет в состоянии самостоятельно пополнять свою базу знаний, используя ресурсы сети Интернет. Это станет возможным, когда технологии семантической сети будут повсеместно использоваться в Интернете. 